\title{
Technology Integration in Nursing Education (Tine): A Proposed Intervention Program
}

\author{
Mae Joy B. Penaflor-Espinosa \\ Woosong University, Daejeon, Republic of Korea \\ maejoyespinosa426@yahoo.com
}

\begin{abstract}
This research study, conducted in 2015, determined the technology integration in nursing education in the six Colleges of Nursing in Western Visayas, Philippines. An intervention program was made to strengthen the ICT integration in the teaching and learning process ii nursing education. The proposed intervention program has three major components that address specific stakeholders namely, the school administrators, the nursing faculty, and the nursing students which are expressed in a triad of E, namely, empowering, enhancing, and enabling, and shall address specific strategies, which include involvement, adaptation, and installation. The entire intervention program was illustrated in a pyramidal structure with the base involving administrators, nursing faculty was placed at the middle, and at the apex are the nursing students. However, the impact of this intervention program is envisioning an inverted pyramid affecting nursing students at the base, nursing faculty at the middle, and the apex with the school administrators.
\end{abstract}

Keywords: Technology Integration, ICT, Nursing Education, ICT Intervention Program

\section{Introduction}

Technological advancement has greatly influenced the higher educational institutions in the $21^{\text {st }}$ century. The information and communication technology (ICT) has become one of the basic building blocks of modern society. Many countries now regard understanding ICT and mastering the basic skills and concepts of ICT as part of the core of education, alongside reading, writing, and numeracy (Division of Higher Education, UNESCO, 2002).

In nursing education, there is a need to integrate technology where the curriculum consists of an overwhelming amount of essential learning material wherein the student must have the advanced knowledge and critical thinking skills necessary to act with accuracy in life-and-death situations. Nursing faculty have responded to these increasing educational needs through the use of technological formats for both classroom and clinical instruction (Iverson, Ball, Harms, Murcek, Woods, \& Young, 2016) and it requires an educator who is prepared to facilitate an effective learning experience (Axley, 2008). Nursing faculty need to prepare students not only to become clinicians to promote health and improve well-being. To attain these, there is a need to redesign the nursing curriculum as technology, science, and the demands of the public for a more effective health care. With today's current information explosion, it is also vital for the faculty to effectively engage today's contemporary learners in the classroom (Turale, 2011).

In the Philippines, integration of technology in the teaching-learning process in nursing education has taken a lot of turns, and there has been a change of paradigm for the better. Despite the importance of preparing nursing students using ICT tools, still nursing educational curricula appear to lack sufficient attention to many basic competencies that 
promote knowledge and skill development in this area (Atthill, 2015). The researcher has also observed that there is limited access to facilities and resources for the students as well as for the nursing faculty. Still in its infancy, these observations highlight the necessity to investigate the nature of the integration of technology in the teaching and learning process in nursing education. The dearth of studies validate therefore the need to investigate how extensively ICT have been integrated in nursing education, the ICT skills of nursing faculty, and the extent of utilization of the resources and facilities as experienced by the students. An intervention program was made to strengthen the ICT integration in the teaching and learning process in nursing education.

\section{Objective of the Study}

This study determined the technology integration in nursing education and its implications to the Colleges of Nursing in Western Visayas, Philippines. Based on the findings, this study has proposed an intervention program to strengthen the information and communication technology integration in the teaching and learning process in nursing education.

\section{Methodology}

This study is a descriptive research, one-shot survey. The study included selected higher education institutions offering Bachelor of Science in Nursing in Western Visayas, Philippines. There are six nursing schools included, three of the nursing schools were taken from the Province of Negros Occidental and the three others were taken from the Province of Iloilo. These six nursing schools were included as the top performing nursing schools in the Philippine Nursing Licensure Examinations in 2013 and 2014. The respondents of the study regarding the available resources and facilities included the Dean, Audio-Visual Resources (AVR) Director, Library Director, and Nursing Arts Laboratory Director. Respondents on the utilization and integration of available resources and facilities were the179 nursing faculty and the 218 fourth year nursing students.

The study has used a researcher-made questionnaire-checklist, on the available technology resources and facilities which have been utilized by the nursing faculty, extent of skill in using information communication technology (ICT), and extent of integration of technology resources and facilities in teaching and learning process. The last portion of the instrument was the information gathered from the nursing students which dealt with the information measuring about the extent of utilization of the available technology resources and facilities and the benefits of integration by the nursing faculty in the teaching and learning process as experienced by the students. The information provided were treated highly confidential and used solely for research. Data gathered were processed and analyzed using the Statistical Package for Social Sciences (SPSS) version 17. The level of significance was set at .05 .

\section{Results and Discussions}

\section{The Available Technology Resources and Facilities for the Colleges of Nursing}

Table 1 shows the available resources and facilities such as equipment, internet, and software applications for the Colleges of Nursing. For equipment, laptops/computers, multimedia projectors, wide screen with stand, televisions, microphones, sound systems, video camera, and low fidelity nursing models were available for use in all of the colleges. Of the six, two (Colleges B and C) had simulation laboratory and only one has avermedia (College F). None of them had high fidelity nursing models. Moreover, internet (emails, world wide web, and webcasting) were available for use in all of the colleges. Chat rooms 
were available in five, except to College $\mathrm{F}$, and podcasting (module classes) which was only available to College C. Software applications like PROQUEST, Microsoft office (Word, Excel, Power Point, and Publisher), SPSS (Statistical Package for Social Sciences), image manipulating software (photoshop), content control software, OPAC (Online Public Access Catalogue), and videoconferencing were available in all of the Colleges of Nursing, while E-library was available found only in College A. The integration of technology in teaching and learning process has always been an important aspect of nursing education which could help facilitate students' learning. It is evident that all of the Colleges of Nursing strive to get updated with the available technology resources and facilities. They aid in the implementation of various strategies, methods, activities in the teaching, and learning process. This is in response to the present trends and demands of the millennial learners that are digital based and text savvy. The classroom is no longer a boring scenario with traditional lecture and discussion rather learners are exposed to information gathered through the net and audio-visual techniques and surely amazed them. This is the evidence of a changing educational process of 21 st century.

Table 1. The Available Technology Resources and Facilities for the Colleges of Nursing

\begin{tabular}{|c|c|c|c|c|c|c|}
\hline $\begin{array}{l}\text { Technology Resources } \\
\& \text { Facilities }\end{array}$ & $\begin{array}{c}\text { College } \\
\text { A }\end{array}$ & $\begin{array}{c}\text { College } \\
\mathrm{B}\end{array}$ & $\begin{array}{c}\text { College } \\
\mathrm{C}\end{array}$ & $\begin{array}{c}\text { College } \\
\mathrm{D}\end{array}$ & $\begin{array}{c}\text { College } \\
\mathrm{E}\end{array}$ & $\begin{array}{c}\text { College } \\
\text { F }\end{array}$ \\
\hline \multicolumn{7}{|l|}{ Equipment } \\
\hline Laptop/Computer & l & I & I & I & I & I \\
\hline Overhead & l & I & l & l & I & I \\
\hline Multimedia Projector & l & I & l & I & / & / \\
\hline Wide Screen with Stand & l & / & l & I & / & / \\
\hline Television & l & / & l & l & / & / \\
\hline Microphone & l & / & l & l & / & / \\
\hline Sound System & I & / & l & I & / & / \\
\hline Video Camera & l & / & l & / & l & / \\
\hline Simulation Laboratory & $\mathrm{x}$ & I & l & $\mathrm{x}$ & $\mathrm{x}$ & $\mathrm{x}$ \\
\hline High Fidelity Models & $\mathrm{x}$ & $\mathrm{x}$ & $\mathrm{x}$ & $\mathrm{x}$ & $\mathrm{x}$ & $\mathrm{x}$ \\
\hline Low-Fidelity Models & l & I & l & I & I & / \\
\hline Avermedia & $\mathrm{x}$ & $\mathrm{x}$ & $\mathrm{x}$ & $\mathrm{x}$ & $\mathrm{x}$ & l \\
\hline \multicolumn{7}{|l|}{ Internet } \\
\hline Emails & l & / & l & / & / & / \\
\hline Chat Rooms & l & I & l & & / & $\mathrm{x}$ \\
\hline World Wide Web & l & / & l & I & / & / \\
\hline $\begin{array}{l}\text { Webcasting (Skype, YM/ Hotmail } \\
\text { Messenger) }\end{array}$ & l & / & / & l & / & / \\
\hline Podcasting (Module Classes) & $\mathrm{x}$ & $\mathrm{x}$ & l & $\mathrm{x}$ & $\mathrm{x}$ & $\mathrm{x}$ \\
\hline \multicolumn{7}{|l|}{ Software/Applications } \\
\hline PROQUEST & l & I & l & I & I & / \\
\hline E-Library & I & $\mathrm{x}$ & $\mathrm{x}$ & $\mathrm{x}$ & $\mathrm{x}$ & $\mathrm{x}$ \\
\hline $\begin{array}{c}\text { Microsoft Office(Word, Excel, } \\
\text { Power point, and Publisher) }\end{array}$ & / & / & l & / & I & / \\
\hline $\begin{array}{l}\text { SPSS (Statistical Package for } \\
\text { Social Sciences) }\end{array}$ & l & / & l & l & l & l \\
\hline $\begin{array}{l}\text { Image Manipulating Software } \\
\text { (Photoshop) }\end{array}$ & l & / & l & I & / & / \\
\hline Content Control Software & I & / & l & I & / & / \\
\hline OPAC (Online Public Access & l & / & l & / & / & l \\
\hline $\begin{array}{l}\text { Catalogue) } \\
\text { Videoconferencing }\end{array}$ & l & / & l & l & l & l \\
\hline
\end{tabular}

Table 2 presents the data on the technology resources and facilities utilized by the nursing faculty in the classroom. Data reveal that there was a high utilization of the equipment such as laptops/computers $(\mathrm{M}=4.00)$, wide screen with stand $(\mathrm{M}=3.72)$ and moderate utilization of multimedia projector $(\mathrm{M}=2.62)$, microphone $(\mathrm{M}=3.00)$, sound 
system $(\mathrm{M}=3.00)$ and minimal utilization of low fidelity models $(\mathrm{M}=2.00)$, television $(\mathrm{M}=2.28)$ and video camera $(\mathrm{M}=2.25)$.

Internet connectivity was high in world wide web $(\mathrm{M}=3.87)$, moderate utilization in emails $(M=3.45)$ and chatrooms $(M=2.65)$, and minimal utilization in webcasting such as skype, yahoo, and hotmail messenger $(\mathrm{M}=2.14)$. During actual classroom interaction with the students, internet connectivity may have minimal utilization for classroom activity. In terms of software applications, nursing faculty teaching in the classroom popularly used Microsoft office with high utilization $(M=4.00)$. These applications were of significantly used in the teaching and learning process.

\section{Table 2. The Technology Resources and Facilities Utilized by the Nursing Faculty in the Classroom}

\begin{tabular}{l|c|l}
\hline Available Technology Resources \& & Mean & \multicolumn{1}{|c}{ Description } \\
Facilities & & \\
\hline Equipment & 4.00 & High utilization \\
Laptop/Computer & 2.62 & Moderate utilization \\
Multimedia Projector & 3.00 & Moderate utilization \\
Microphone & 3.00 & Moderate utilization \\
Sound System & 3.72 & High utilization \\
Wide Screen with Stand & 2.00 & Minimal utilization \\
Low Fidelity Models & 2.28 & Minimal utilization \\
Television & 2.62 & Moderate utilization \\
Overhead Projector & 2.25 & Minimal utilization \\
Video Camera & & \\
Internet & 3.45 & Moderate utilization \\
Emails & 3.87 & High utilization \\
World Wide Web & 2.66 & Moderate utilization \\
Chatrooms & 2.14 & Minimal utilization \\
Webcasting (via Skype, YM or & & \\
Hotmail Messenger) & & \\
Software/Applications & & \\
Microsoft Office (Word, Excel, Power & 4.00 & High utilization \\
point, and Publisher) & 2.00 & Minimal utilization \\
Content Control Software & 2.14 & Minimal utilization \\
SPSS (Statistical Package for Social & & \\
Sciences) & 1.50 & Minimal utilization \\
PROQUEST & 1.83 & Minimal utilization \\
Image Manipulating Software & \\
(Photoshop) & 2.00 & Minimal utilization \\
OPAC & Minimal utilization \\
Videoconferencing & \\
\hline
\end{tabular}

Table 3 shows the technology resources and facilities utilized by the nursing faculty in the clinical area. Majority of the nursing faculty assigned in clinical area had minimal to moderate utilization of technology resources which could be due to the limitations set forth by the affiliating agencies and the limited resources available in the area of assignment. 


\section{Table 3. The Technology Resources and Facilities Utilized by the Nursing} Faculty in the Clinical Area

\begin{tabular}{|c|c|c|}
\hline $\begin{array}{l}\text { Available Technology Resources \& } \\
\text { Facilities }\end{array}$ & Mean & Description \\
\hline $\begin{array}{l}\text { Equipment } \\
\text { Laptop/Computer } \\
\text { Multimedia Projector } \\
\text { Microphone } \\
\text { Sound System } \\
\text { Wide Screen with Stand } \\
\text { Low Fidelity Models } \\
\text { Television } \\
\text { Overhead Projector } \\
\text { Video Camera }\end{array}$ & $\begin{array}{l}3.08 \\
1.97 \\
2.16 \\
2.06 \\
1.75 \\
0.00 \\
1.61 \\
1.53 \\
1.51\end{array}$ & $\begin{array}{l}\text { Moderate utilization } \\
\text { Minimal utilization } \\
\text { Minimal utilization } \\
\text { Minimal utilization } \\
\text { Minimal utilization } \\
\text { Low utilization } \\
\text { Minimal utilization } \\
\text { Minimal utilization } \\
\text { Minimal utilization }\end{array}$ \\
\hline $\begin{array}{l}\text { Internet } \\
\text { Emails } \\
\text { World Wide Web } \\
\text { Chatrooms } \\
\text { Webcasting (via Skype, YM or } \\
\text { Hotmail Messenger) }\end{array}$ & $\begin{array}{l}2.61 \\
2.32 \\
1.64 \\
1.46\end{array}$ & $\begin{array}{l}\text { Moderate utilization } \\
\text { Minimal utilization } \\
\text { Minimal utilization } \\
\text { Low utilization }\end{array}$ \\
\hline $\begin{array}{l}\text { Software/Applications } \\
\text { Microsoft Office (Word, Excel, Power } \\
\text { point, and Publisher) }\end{array}$ & 2.65 & Moderate utilization \\
\hline $\begin{array}{l}\text { Content Control Software } \\
\text { SPSS (Statistical Package for Social } \\
\text { Sciences) }\end{array}$ & $\begin{array}{l}0.00 \\
1.70\end{array}$ & $\begin{array}{l}\text { Low Utilization } \\
\text { Minimal utilization }\end{array}$ \\
\hline $\begin{array}{l}\text { PROQUEST } \\
\text { Image Manipulating Software } \\
\text { (Photoshop) }\end{array}$ & $\begin{array}{l}1.20 \\
1.84\end{array}$ & $\begin{array}{l}\text { Low utilization } \\
\text { Minimal utilization }\end{array}$ \\
\hline $\begin{array}{l}\text { OPAC } \\
\text { Videoconferencing }\end{array}$ & $\begin{array}{l}1.70 \\
0.00\end{array}$ & $\begin{array}{l}\text { Minimal utilization } \\
\text { Low utilization }\end{array}$ \\
\hline
\end{tabular}

The summary of the technology resources and facilities utilized by the nursing faculty, both in the classroom and clinical area are presented in Table 4 . The data reveal that there was high utilization in the usage of equipment such as laptops/computers $(\mathrm{M}=3.84)$ and multimedia projector $(\mathrm{M}=3.52)$, and software applications such as Microsoft office $(\mathrm{M}=3.82)$. There were moderate utilization in terms of equipment such as microphone $(M=3.00)$, sound system $(M=3.04)$, and wide screen with stand $(M=2.79)$, internet such as e-mails $(\mathrm{M}=3.33)$ and world wide web $(\mathrm{M}=3.16)$, and software and applications such as content control software $(\mathrm{M}=2.80)$ and PROQUEST $(\mathrm{M}=3.30)$. Videoconferencing was found to have low utilization $(\mathrm{M}=1.40)$. 
Table 4. Summary Table of Technology Resources and Facilities Utilized by the Nursing Faculty in the Classroom and Clinical Area

\begin{tabular}{|c|c|c|}
\hline $\begin{array}{l}\text { Available Technology Resources \& } \\
\text { Facilities }\end{array}$ & Mean & Description \\
\hline $\begin{array}{l}\text { Equipment } \\
\text { Laptop/Computer } \\
\text { Multimedia Projector } \\
\text { Microphone } \\
\text { Sound System } \\
\text { Wide Screen with Stand } \\
\text { Low Fidelity Models } \\
\text { Television } \\
\text { Overhead Projector } \\
\text { Video Camera }\end{array}$ & $\begin{array}{l}3.84 \\
3.52 \\
3.00 \\
3.04 \\
2.79 \\
2.20 \\
1.69 \\
1.83 \\
1.84\end{array}$ & $\begin{array}{l}\text { High utilization } \\
\text { High utilization } \\
\text { Moderate utilization } \\
\text { Moderate utilization } \\
\text { Moderate utilization } \\
\text { Minimal utilization } \\
\text { Minimal utilization } \\
\text { Minimal utilization } \\
\text { Minimal utilization }\end{array}$ \\
\hline $\begin{array}{l}\text { Internet } \\
\text { Emails } \\
\text { World Wide Web } \\
\text { Chatrooms } \\
\text { Webcasting (via Skype, YM or } \\
\text { Hotmail Messenger) }\end{array}$ & $\begin{array}{l}3.33 \\
3.16 \\
2.32 \\
2.22\end{array}$ & $\begin{array}{l}\text { Moderate utilization } \\
\text { Moderate utilization } \\
\text { Minimal utilization } \\
\text { Minimal utilization }\end{array}$ \\
\hline $\begin{array}{l}\text { Software/Applications } \\
\text { Microsoft Office (Word, Excel, Power } \\
\text { point, and Publisher) }\end{array}$ & 3.82 & High utilization \\
\hline $\begin{array}{l}\text { Content Control Software } \\
\text { SPSS (Statistical Package for Social } \\
\text { Sciences) }\end{array}$ & $\begin{array}{l}2.80 \\
2.14\end{array}$ & $\begin{array}{l}\text { Moderate utilization } \\
\text { Minimal utilization }\end{array}$ \\
\hline $\begin{array}{l}\text { PROQUEST } \\
\text { Image Manipulating Software } \\
\text { (Photoshop) }\end{array}$ & $\begin{array}{l}3.30 \\
1.99\end{array}$ & $\begin{array}{l}\text { Moderate utilization } \\
\text { Minimal utilization }\end{array}$ \\
\hline $\begin{array}{l}\text { OPAC } \\
\text { Videoconferencing }\end{array}$ & $\begin{array}{l}1.90 \\
1.40\end{array}$ & $\begin{array}{l}\text { Minimal utilization } \\
\text { Low utilization }\end{array}$ \\
\hline
\end{tabular}

\section{Information and Communication Technology (ICT) Skills of the Nursing Faculty}

The data reveal that the respondents' the ICT skills were moderate $(\mathrm{M}=3.35)$. They were highly skilled in starting, setting-up, and closing of digital data $(\mathrm{M}=3.53)$. They were also moderately skilled in exploring, receiving, storing, utilizing, applying, and sharing of digital data ( $\mathrm{M}=3.39$ and $\mathrm{M}=3.15$, respectively).

\section{Table 5. Information and Communication Technology (ICT) Skills of the Nursing Faculty}

\begin{tabular}{lcl}
\hline Information and Communication Technology (ICT) Skills & Mean & Description \\
\hline 1. Starting, setting-up, and closing of digital data & 3.53 & Highly Skilled \\
2. Exploring, receiving, and storing of digital data & 3.39 & Moderately Skilled \\
3. Utilizing, applying, and sharing of digital data & 3.15 & Moderately Skilled \\
Over-all & $\mathbf{3 . 3 5}$ & Moderately Skilled \\
\hline
\end{tabular}

Mean Range

3.50-4.00

2.50-3.49

1.50-2.49

1.00-1.49

\section{Description}

Highly Skilled

Moderately Skilled

Poorly Skilled

Not Skilled 
The extent of technology integration of the nursing faculty in the teaching and learning process (preparation, delivery, and evaluation) were moderate $(M=3.33)$. The findings of Ratsogi and Malhotra (2013) and Redmann, Kotrlik, and Douglas (2008) have supported the current findings. Ratsogi and Malhotra's (2013) findings resulted to an average level of ICT integration among teachers. Furthermore, Redmann, Kotrlik, and Douglas (2008) had fair result in the exploration and adoption of technology for regular use in instruction. Teachers did not integrate technology into their instructions because they have no access to these technologies for students' learning.

\section{Table 6. The Extent of Technology Integration of the Nursing Faculty in the Teaching and Learning Process}

\begin{tabular}{lcl}
\hline Extent of Technology Integration & Mean & \multicolumn{1}{c}{ Description } \\
\hline Instructional Preparation & 3.31 & Moderately Integrated \\
Instructional Delivery & 3.42 & Moderately Integrated \\
Instructional Evaluation & 3.26 & Moderately Integrated \\
Over-all & $\mathbf{3 . 3 3}$ & Moderately Integrated \\
\hline
\end{tabular}

Mean Range

$3.50-4.00$

$2.50-3.49$

$1.50-2.49$

$1.00-1.49$

\author{
Description \\ Highly integrated \\ Moderately integrated \\ Poorly integrated \\ Not integrated
}

Table 7 shows the technology resources utilized by the nursing faculty as experienced by the nursing students. The data reveal that power point presentation was highly utilized by the faculty in College $\mathrm{F}(\mathrm{M}=3.93)$. Audiovisual slides and files $(\mathrm{M}=3.43)$, instructional videos, procedures, and documentation $(\mathrm{M}=3.15)$, video clips $(\mathrm{M}=3.10)$, online research works and updates $(\mathrm{M}=3.08)$, and web-based assignments, projects, and activities $(\mathrm{M}=2.96)$ were only moderately utilized by the nursing faculty. Computer-based virtual simulations $(M=2.42)$ and online quiz and test $(M=1.86)$, however, were the least utilized. Overall the nursing students have experienced moderate utilization $(\mathrm{M}=2.99)$ of technology-based teaching tools by the nursing faculty.

\section{Table 7. The Extent of Utilization of the Available Technology Resources and Facilities of Nursing Faculty as Experienced by the Colleges of Nursing Students}

\begin{tabular}{lcl}
\hline \multicolumn{1}{c}{ ICT Tools } & Mean & \multicolumn{1}{c}{ Description } \\
\hline Powerpoint Presentation & 3.93 & High utilization \\
Videoclips & 3.10 & Moderate utilization \\
Audiovisual slides/files & 3.43 & Moderateutilization \\
Instructional videos/procedures/documentation & 3.15 & Moderate utilization \\
Online research works/updates & 3.08 & Moderate utilization \\
Web-based assignments. projects, activities & 2.96 & Moderate utilization \\
Computer-based virtual simulations & 2.42 & Minimal utilization \\
Online quiz and tests & 1.86 & Minimal utilization \\
\multicolumn{1}{c}{ Overall } & 2.99 & Moderate utilization \\
\hline
\end{tabular}

The top three benefits of integrating technology in the teaching and learning process as experienced by nursing students were the following: it made students happy with their learning $(\mathrm{M}=3.58)$, helped in communication and collaboration $(\mathrm{M}=3.50)$ and allowed students to enjoy varied learning activities $(M=3.48)$. The lowest mean scores, but were 
still equivalent to a moderately beneficial assessment were registered by the perception that technology has improved school-related requirements $(M=3.49)$, enjoyed varied learning activities $(M=3.48)$, motivated and attentive in class $(M=3.39)$, and confident in new knowledge gained $(\mathrm{M}=3.39)$. The over-all result show moderate extent of benefit of the integration of technology resources and facilities by the nursing faculty in teaching and learning process. This indicates that technology integration can increase students' motivation and foster positive attitude towards learning. Students in technology-enhanced classrooms are more likely to have enjoyable and meaningful learning experiences. This encourages the students to look optimistically towards learning with technology and enhances their outcomes. Thus, technology integration in the teaching and learning benefits the students in numerous ways in their quest for life-long learning.

\section{Table 8. The Extent of Benefit of Integration of Technology Resources and Facilities by the Colleges of Nursing Faculty in the Teaching and Learning Process as Experienced by the Nursing Students}

\begin{tabular}{lcl}
\hline \multicolumn{1}{c}{ Extent of Benefits } & Mean & \multicolumn{1}{c}{ Description } \\
\hline Motivated and attentive in class & 3.39 & Moderately beneficial \\
Participated lesson for the day & 3.32 & Moderately beneficial \\
Enjoyed varied learning activities & 3.48 & Moderately beneficial \\
Confident in new knowledge gained & 3.39 & Moderately beneficial \\
Improved school-related requirements & 3.49 & Moderately beneficial \\
Happy with what have learned & 3.58 & Highly beneficial \\
Had better grades & 3.19 & Moderately beneficial \\
Increased interest in the subject matter & 3.36 & Moderately beneficial \\
Allowed greater control of class activities & 3.32 & Moderately beneficial \\
Helped in communication and collaboration & 3.50 & Highly beneficial \\
\multicolumn{1}{c}{ Overall } & 3.40 & Moderately beneficial \\
\hline
\end{tabular}

Most of the students hold the belief that the use of technology facilitates deeper understanding of conceptually difficult information and made them happy with what they have learned, helped them communicate and collaborate, and eventually improved schoolrelated requirements. This supported by the excerpts from the focus group discussion done.

"Nasadyahan gid ako sang mga technologies nga ini hay nakabulig gid visualize nga indi mo makita sa libro, ginabasa namom ukon nabatian". (I am happy with these technologies because it really helps in visualizing things that you would not get out of reading a book or by hearing them)

One of the students expressed that it increases confidence and build skills in the subject matter.

As verbalized, "Sa amon nga lecture, ang mga technologies nga ini makabulig hatag sang mga major points which improved my confidence". (During lecture, technology will help you in giving major points which have helped increase my confidence)

"Helpful gid katama ang mga technology na ini, like when doing research, dapat reliable gid ang mga resources which nagapa help improve sang amon mga grades. And sa amon quizzes, grabe gid ang pagbulig sa amon performance which brings about easy recall of a certain topic". (Technology like this can be very helpful especially in doing research. Resources should be reliable which can help us improve our grades. In our quizzes, technology has greatly helped in improving our performance because it brings about easy recall of certain topics)

"Academically, these technologies can help improve my performance sa school. Daw compact na abi ang tanan kag ara lang sa isa ka suludlan. I mean, pagbukad mo, ara dayun sa folder". (Academically, these technologies can help improve my performance in school. It's as if lessons are compact and are in one folder. I mean, when you open it, all 
the lessons are there).

"Grabe gid ang pag bulig improve academically sang mga technology nga ini, like gina enhance niya gid ang imo pag intindi sang mga topics nga indi mu kun kaisa

ma-understand kun gina read mo lang". (Technology has greatly helped us improve academically. It enhances our understanding of topics that otherwise we may not understand if we only read about it in our textbooks)

"In terms of grades, grabe ang na help sa akon. Na enhance gid ang akon audio-visual perception, especially kun mag exams kami nga ma recall ko gid ya tanan tanan. As in, very clear gid". (In terms of grades, it has greatly helped me. It enhanced my audio-visual perception especially during exams because I can easily recall all lessons clearly).

Most of the students believed that the use of technology by the nursing faculty greatly enhances students' learning. They expressed a nearly unanimous conclusion that the utilization of these technologies was the best and highly beneficial to their learning. This supports the study of Souter (2013) that integrating technology in the classroom increased student's achievement and attitude. Students who were in exposed to technology in the classroom had higher achievement scores, were more motivated, and had more positive attitude than those in traditional classrooms. In the same way, Maboe and de Villiers (2011) also found that technology integration in the classroom enhances students' motivation to learn, established own pace of learning, and gave sense of control in learning and enable students to achieve learning objectives to obtain more information.

\section{Summary of Findings}

1. The available technology resources and facilities in the six colleges of nursing were laptops/computers, multimedia projectors, wide screen with stand, televisions, microphones, sound systems, video cameras, emails, world wide web, and webcasting. Software/application like PROQUEST, Microsoft office (Word, Excel, Power Point, and Publisher), SPSS (Statistical Package for Social Sciences), image manipulating software (Photoshop), content control software, OPAC (Online Public Access Catalogue), and videoconferencing were also the common technologies found in the sic colleges of nursing. Laptops and computers, world wide web, multimedia projector, and Microsoft Office were highly utilized by the nursing faculty in the classroom and clinical area.

2. The over-all ICT skills of the nursing faculty and the extent of technology integration of nursing faculty in the teaching and learning process were moderate $(\mathrm{M}=3.35$ and $\mathrm{M}=3.33)$.

3. The extent of utilization of the available technology resources and facilities of nursing faculty as experienced by the nursing students was moderate $(M=2.99)$. Powerpoint presentation was highly utilized.

4. The nursing students had experienced moderately beneficial $(M=3.40)$ in the integration of technology resources and facilities of nursing faculty in teaching and learning process.

5. The top three benefits of integrating technology in the teaching and learning process as experienced by nursing students were making the students happy with their learning $(\mathrm{M}=3.58)$, helping them in communication and collaboration $(\mathrm{M}=3.50)$ and allowing them to enjoy varied learning activities $(\mathrm{M}=3.48)$.

\section{Conclusions}

The integration of technology can make a measurable difference in teaching and in the learning process in nursing education. Therefore, in order to accomplish the profound changes associated with the integration of technology in the overall learning environment and to enhance teaching and learning process, there is a real need for the administration to 
increase their enabling capacity to revise their vision and educational philosophy, resource capitalization, installation and provision of access to technological equipment, and feedback mechanisms on the impact of technology in education, develop the enhancing capacity of the nursing faculty in using technology in educating their students (preparation, delivery, and evaluation) as evidenced by the presence of capability-building programs, creative lesson planning and blended learning, and adaptation to technological use, and empowering the nursing students with the aid of technology in their educational processes as evidenced by exposure to technological resources and their active participation in the use of technology in classroom and clinical settings, involvement in curricular designing, and impact assessment on the benefits and effectiveness of technology in their learning

\section{Proposed Intervention Program for Technology Integration in Nursing Education (TINE)}

The proposed intervention program has three major components that address specific stakeholders namely, the school administrators, the nursing faculty, and nursing students.

The major objectives are expressed in a triad of $\boldsymbol{E}$ namely:

- To acquire the necessary nursing competencies, thus empowering the students with the aid of the technology in their educational processes.

- To further develop the enhancing capability of the nursing faculty in using technology in educating their students (Instructional Preparation, Instructional Delivery, and Instructional Evaluation).

- To increase the enabling capacity of the school administration for effective and efficient integration of technology in teaching and learning of nursing students.

Further these proposed intervention programs shall address specific strategies particularly:

- Involvement of nursing students in curriculum designing, exposure and experience. An impact study on the academic performance of these nursing students can prove to be very beneficial.

- Adaptation of the nursing faculty to technological use, engaging in capability programs, creative lesson planning, and blended learning.

- Installation of strategic feedback mechanism, updates of educational vision, human and resources capitalization, strategic E-resources-capital resources.

The entire intervention program is illustrated in a pyramidal structure with the base involving administrators, nursing faculty was placed at the middle, and at the apex are the nursing students. However, the impact of this intervention program is envisioning an inverted pyramid affecting nursing students at the base, nursing faculty at the middle, and the apex with the school administrators (Figures 1 and 2). 


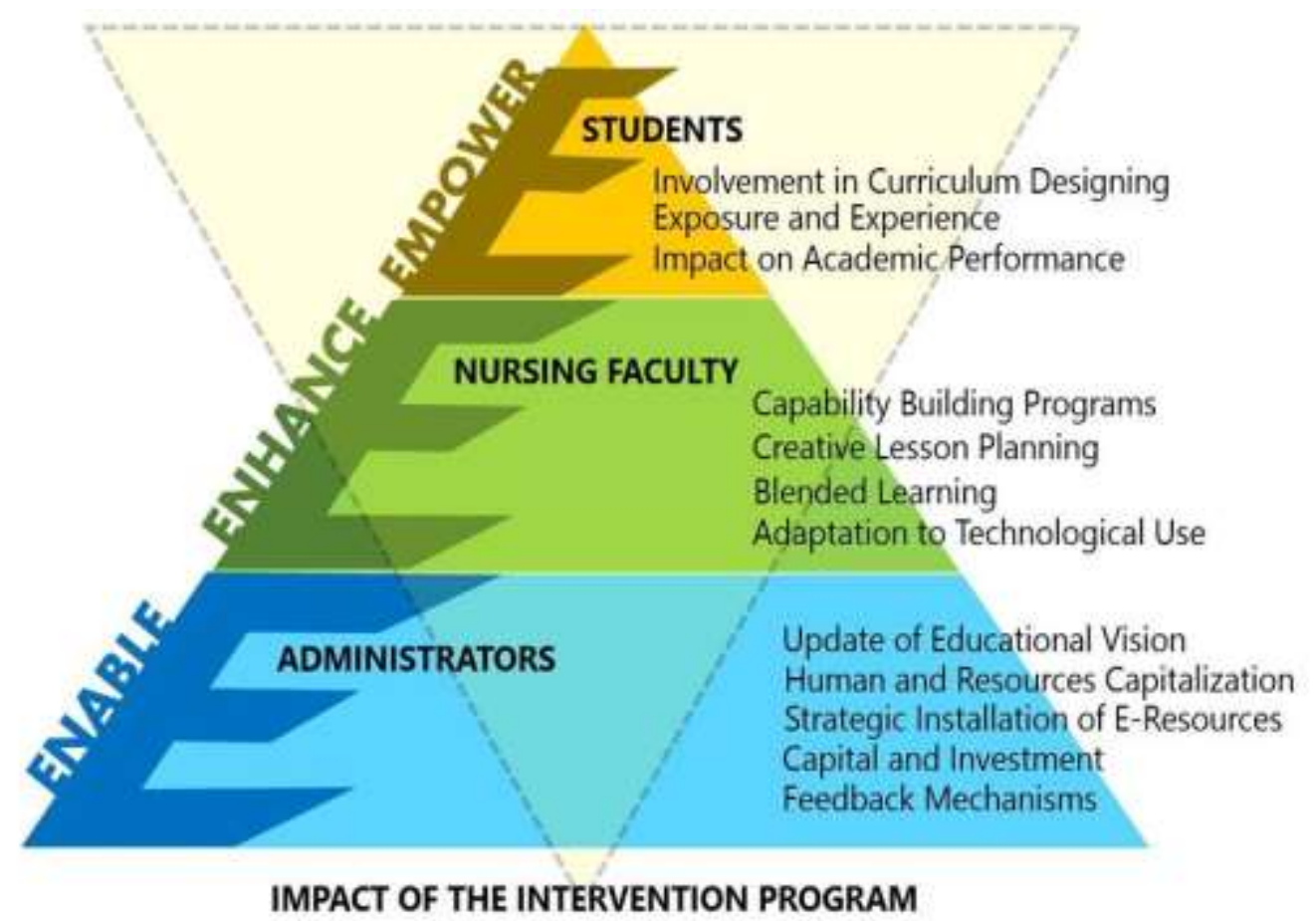

Figure 1. Impact of Intervention Program in Nursing Education

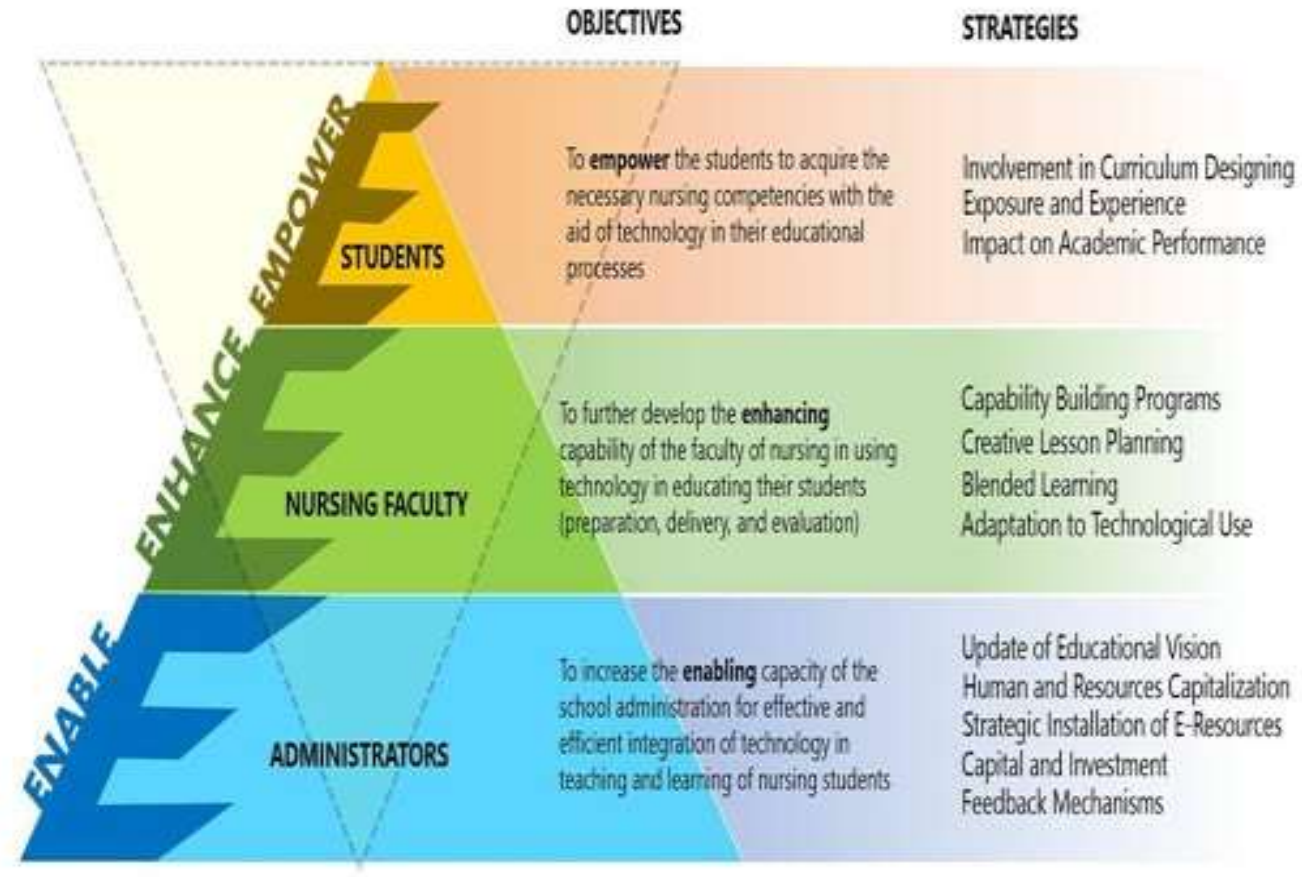

Figure 2. Impact of Intervention Program in Nursing Education with Specific Strategies 


\title{
References
}

[1] Division of Higher Education, United Nations Educational, Scientific, and Cultural Organization, "Information and communication technology in education: a curriculum for schools and programme of teacher development", (2002).

[2] L. Iverson, S. Ball, A. Harms, C. Murcek, S. Woods and T. Young, "Technology in the college of nursing: perception and use to achieve learning outcomes", Online Journal of Nursing Informatics, vol. 20, no. 1, (2016).

[3] L. Axley, "The integration of technology into nursing curricula: supporting faculty via the technology fellowship program", OJIN: The Online Journal of Issues in Nursing, vol. 13, no. 3, (2008).

[4] L. Axley, "The integration of technology into nursing curricula: supporting faculty via the technology fellowship program", OJIN: The Online Journal of Issues in Nursing, vol. 13, no. 3, (2008).

[5] S. Atthill, "An exploration of the influence of nursing education culture on the integration of nursing informatics competencies into a collaborative nursing program curriculum", Electronic Thesis and Dissertation Repository Paper, (2015).

[6] Rastogi and S. Malhotra, "ICT skills and attitude as determinants of ICT pedagogy integration", European Academic Research, vol. 1, no. 2, (2012).

[7] D. Redmann and J. Kotrlik, "A trend study: technology adoption in the teaching-learning process by secondary business teachers- 2002 \& 2007", The Delta Pi Epsilon Journal, L vol. 2, (2008), pp. 77-89.

[8] K. A. Maboe and L. de Villiers, "Computer-assisted instruction in nursing education in South Africa", Africa Journal of Nursing and Midwifery, vol. 13, no. 1, (2011).

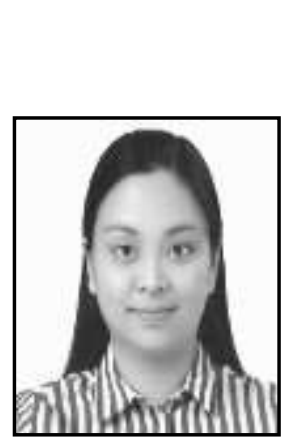

\begin{abstract}
Author
Mae Joy P. Espinosa, PhD, RN is an Assistant Professor in Woosong University, Daejeon, Republic of Korea. She had been a Lecturer in the Department of Adult and Critical Care, College of Nursing, Sultan Qaboos University, Muscat, Oman. She has made significant contributions to patient care through teaching, lectures, leadership activities, and professional activities both in graduate and undergraduate nursing.
\end{abstract}

